THE PRODUCTIVITY AND EFFICIENCY OF BORDER LEICESTER $\times$ CHEVIOT, FINN $\times$ BLACFACE AND EAST FRIESLAND $\times$ BLACKFACE PROLIFIC CROSS-BRED EWES FOR LAMB AND CARCASS MEAT PRODUCTION IN ENGLAND

W. M. Tempest, T. G. Boaz, R. Jones. - The University of Leeds, Department of Animal Physiology and Nutrition, U.K.

Experiments have been carried out over 8 years to investigate systems of lamb production designed to make the fullest use of grassland, based on high levels of prolificacy of the ewes and high annual stocking rates per hectare.

The results show that for suckled fat lamb production, both the Bovder Leicester/Cheviot and East Friesland/Blackface crosses possess the necessary attributes of prolificacy and high milk yield, but the smaller size of the latter enables higher output per hectare to be obtained. The Finn /Blackface cross, despite higher prolificacy and smaller size, are less efficient for suckled fat lamb production, but have merit for producing " store " lambs for subsequent winter fattening.

REPRODUCTION AND ADAPTATION ABILITIES OF EASTFRIESIAN SHEEP IN THE ČR

B. Cumlivski. - Research Institute of Animal Production Praha 1o-Uhrineves, CSSR.

During the years 1969-I975 the prolificity and adaptability of 42 sheep, I 4 rams and their offspring of Eastfriesian breed were followed. The sheep and rams were from GDR imported wbere they were kept in small numbres of $\mathrm{I}-5$ animals. In our country this animals were kept together with other sheep breeds in a herd of $180-45^{\circ}$ animals. The individual tupping occured: at an age of I6-I9 months from I August to 31 October of each year. No synchronisation checks. took place. The lambs were kept till to the age of 4 months with their mothers. The daily feed rations for the sheep: $2,470 \mathrm{~kg}$ dry matter, $0,155 \mathrm{~kg}$ digestible protein and I, $10 \mathrm{~kg}$ Ste; for the lambs: $1,824 \mathrm{~kg}$ dry matter, $0,158 \mathrm{~kg}$ digestible protein and $1,024 \mathrm{~kg}$ Ste.

Imported sheep: Average recurrence of oestrus till to the conception (I-V lambing) occured 2,39 times. 6r,7 per cent of sheep became pregnant. The prolificity of the tupped sheep. amounted to I28, I per cent. Exit of lambs 35,3 per cent.

Sheep born in our country: Average occurence of oestrus till to the conception (I-V lambing) occured I,06 times. 93,75 per cent of sheep became pregnant. The prolificity amounted to. I 43,3 per cent and the exit of lambs 2,2 per cent.

The adaptability of the imported Eastfriesian sheep to the herd breeding is fairly low, especially in the worse conditions in which case the efficiency and disease-resistance and thestate of health are reduced. If the Eastfriesian sheep and lambs were born and kept in a herd their adaptation and reproduction abilities and the state of health were considerably better.

The observation of the Easftriesian sheep will continue.

\title{
FINNISH LANDRACE \ BORDER LEICESTER RAMS AS SIRES OF CROSSBRED EWES
}

F. K. Deeble $\left(^{*}\right)$ and J. D. Barker (**). - (*) Agricultural Development and Advisory Service, Reading, U. K. (**) Animal Breeding Research Organisation, Edinburgh, U. K.

The use of Finnish Landrace /Border Leicester rams to produce crossbred ewes, in place of the more traditional ram breeds used for crossbreeding, has resulted in lambing percentages being increased by about 14 per cent and rearing percentages increased by about 16 per cent over four lamb crops. Although individual lamb weights have been reduced by 6 per cent at ten weeks, the weight of lamb produced per ewe mated was 6 per cent greater from the Finnish Landrace /Border Leicester crosses. These figures for increased lambing percentages and decreased individual lamb weights are about one half of the values found when purebred Finnish Landrace rams were used as alternative crossbreeding sires, and hence are not unexpected. The advantage in using Finnish Landrace/Border Leicester rams instead of pure Finnish Landrace rams lies in the easier management of the crossbred ewes and their lambs, because of the more easily handled lambing percentages and relatively heavier lambs.

The improvement in prolificacy from the Finnish Landrace /Border Leicester crosses occured in the $\mathrm{I}$ year old and 2 year old dams particularly but was less marked in the older ewes. Furthermore, the differences in ewe weights, prior to mating, between the Finnish Landrace /Border 